\title{
Validation of Alternative Methods of Detection of Salmonella Spp. in Experimentally Contaminated Poultry Environmental Samples
}

Original Article

\section{-Author(s)}

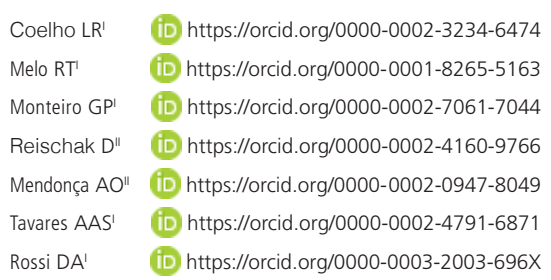

Rossi DA'

Laboratory of Molecular Epidemiology, Faculty of Veterinary Medicine, Federal University of Uberlândia, Uberlândia, Minas Gerais, Brazil.

National Agricultural Laboratory (LANAGRO), Ministry of Agriculture, Livestock and Supply (MAPA), Campinas, São Paulo, Brazil.

\section{Mail Address}

Corresponding author e-mail address Roberta Torres de Melo

Universidade Federal de Uberlandia, Ceará Street, room 2D43 - Umuarama Uberlandia 38408-100, Brazil.

Phone: +55(34)32132319

Email: roberta.tmelo@ufu.br

\section{- Keywords}

BAX ${ }^{\circledR}$ System, MSRV, Salmonella Enteritidis, S. Typhimurium, Molecular biology.

\section{ABSTRACT}

The analysis of Salmonella in the feces and the birds' environment is a way of monitoring the colonization in the flocks and verifying the need for the introduction of stricter controls, in such a way that the results of the tests should be known before being sent for slaughter. The polymerase chain reaction (PCR), as well as other rapid methods represent alternatives increasingly used to detect enteric pathogens, but they need proof of effectiveness for their wide use. The aim of this study was to evaluate the equivalence between the results obtained by the methods: real-time PCR (BAX ${ }^{\circledR}$ System), Modified RappaportVassiliadis Semi-solid Medium (MSRV) (ISO 6579) and the traditional method of official reference in Brazil for research of $S$. Typhimurium and $S$. Enteritidis in poultry samples. Two hundred and fifty-two samples of disposable shoe covers (DSC) and 252 samples of feces were infected with an average of 2 to $3 \mathrm{log}$ CFU/g of each serovar, and the same samples without fortification were evaluated by the three methods. Five hundred and four diagnoses were obtained with satisfactory results in terms of repeatability (greater than $80 \%$ ), reproducibility (mean $83,1 \%$ ), sensitivity ( $81 \%$ to $100 \%)$, specificity (95\% to $100 \%$ ), and accuracy (90\% to $100 \%)$. The compliance test verified that there was not a significant difference between the alternative and the official methods, allowing us to state that the methodologies have had equivalent performances.

\section{INTRODUCTION}

The intense international market in food of animal origin facilitates the dissemination of variable strains of Salmonella spp. This context receives greater prominence when considering its relevance in public health, being one of the main pathogens involved in food gastroenteritis, and in the economy of the poultry sector, due to the slaughter and disposal of positive flocks (ABPA, 2020; SVS, 2019; Soria et al., 2017).

Although humans can be infected with Salmonella spp. through a wide range of food products, poultry meat and eggs are among the sources most often implicated in human salmonellosis outbreaks. Thus, the use of methodologies that associate high sensitivity, specificity, and speed of diagnosis are extremely important (SVS, 2019).

The most relevant serovars in public health include Salmonella Enteritidis (SE) and Typhimurium (ST) and do not cause mortality in chicken flocks and therefore samples collected in the environment and feces tend to more easily indicate their presence, as they are useful, effective and less invasive (IN 20, 2016). The analysis before the slaughter process allows interventions and the implementation of control measures in order to reduce the risk of contamination of the carcasses during slaughter and the maintenance of the bacteria in the environment (Young et al., 2017). 
Several methodologies are approved by national and international regulatory bodies for research of Salmonella in environmental samples. However, most of them are laborious and time-consuming, requiring many analysts, several days to obtain the results and a large physical space in the laboratories.

The Regulation of the European Commission (EC) ( $n^{\circ}$ 200/2012) establishes as a condition for the export of broiler's carcasses and meat, that all flocks are analyzed for the presence of SE and ST in all stages of production, as they are pathogens of great relevance in public health. Despite this, the legal bias is due to the absence of a quantitative assessment that would be relevant, since both exposure and bacterial load contributed to infection and disease in humans.

To guarantee this monitoring, the routine analysis in the industries must be carried out quickly and simply, however, without compromising the quality of the results. With this, we proposed to verify the equivalence of the alternative methodologies real-time PCR (BAX ${ }^{\circledR}$ System) and MSRV (Modified Semi-solid Rappaport-Vassiliadis) (ISO 6579, 2002), concerning the official Brazilian method, described in Portaria $\mathrm{n}^{\circ}$ 126 of MAPA (Ministry of Agriculture, Livestock and Supply); (Brasil, 1995), to determine SE and ST in environmental samples.

\section{MATERIAL AND METHODS}

\section{Design of the experiment}

The experiment consisted of analyzing feces samples and DSC to compare alternative methodologies (MRSV and BAX) with the traditional one. Strains of SE and ST were previously ribotyped using the Riboprinter ${ }^{\circledR}$ device to confirm purity. Before starting the steps (inoculations), the best and smallest inoculum detectable by the gold standard to be used in the tests was determined. After this determination, the samples were prepared to be analyzed by the three methodologies. This preparation consisted of inoculation of SE and ST, separately, and in each stage, 28 samples were prepared (14 feces - seven with SE and seven with ST, and 14 DSC - seven with SE and seven with ST). The same number of samples, without inoculum (control), was used in each phase. For each procedure, three repetitions were performed, using different strains, totaling 504 samples (252 feces and 252 DSC samples) (Figure 1).

\section{Location, sampling and strains}

The study was carried out at the National Agricultural Laboratory of São Paulo (LANAGRO-SP), Campinas, São Paulo. For the research, feces and environmental
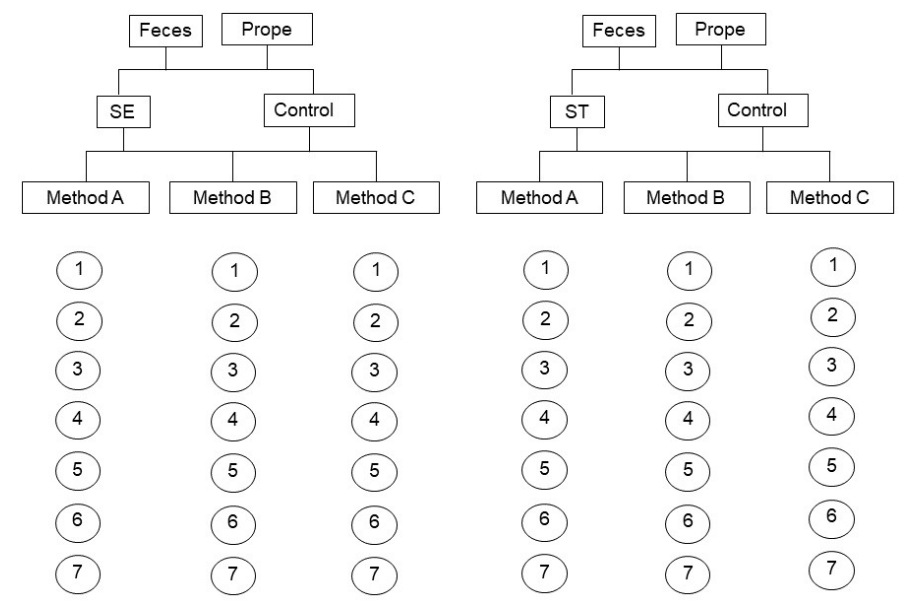

Figure 1 - Schematic analysis procedure for the two types of matrices (feces and DSC), serotypes (SE and ST), and methodologies used: A (official traditional reference methodology in Brazil) B (Modified Rappaport-Vassiliadis Semi-solid Medium - MSRV) and C (real-time PCR - BAX ${ }^{\circledR}$ System).

samples collected by DSC from SPF (Specific Pathogen Free) birds (table-egg, White Leghorn lineage) were used, simulating collections performed in the field (IN 20, 2016).

For the contamination of the samples, three strains of SE and three of ST were used. One of the SE strains corresponds to ATCC 13076 (American Type Culture Collection) and the others of SE and ST are wild strains of poultry origin, belonging to the LANAGRO-SP strain bank. The phenotypic characterization and their typification were performed through biochemical tests and ribotyping (Riboprinter ${ }^{\circledR}$ ), respectively.

\section{Determination of experimental inoculum}

This procedure was performed using the gold standard Salmonella identification method, corresponding to the traditional protocol (Brasil, 1995). In the fortification of the samples, an association of strains of SE and ST previously ribotyped was used. To determine the ideal minimum amount of Salmonella cells that would be used in the experiment, inoculants ranging from 2 to $3 \log$ CFU were used in four replicates of ten feces samples containing the association of strains in Buffered Peptone Water (BPW) $\left(\mathrm{MERCK}^{\circledR}\right)$, representing the replicates. In parallel, a control sample was used for each replicate.

The confirmation of the number of Salmonella cells and also the purity of the strains were made on Rambach agar $\left(\mathrm{MERCK}^{\circledR}\right)$. The experimental inoculum used was the one in which there was positivity in at least 5/10 (50\%) replicates of each repetition.

\section{Sample collection and preparation}

The collection of the material used in the experiment was carried out in compliance with the biosafety rules 
of the Vivarium Unit of LANAGRO-SP. The feces were removed from the SPF bird trays using sterile tweezers, placed in a beaker, and closed for further processing. The feces were collected from SPF birds, to ensure that all Salmonella recovered in the analyzes came from the experimental inoculum.

For the simulation of the environmental samples, DSC were placed on the feet and stepped on trays containing the birds' feces. The material was properly closed to be processed. The collection was carried out according to Normative Instruction $n^{\circ} 20$ (2016).

For feces samples used in the traditional method, non-selective enrichment was made in $20 \mathrm{~mL}$ of brain and heart infusion broth $(\mathrm{BHI})\left(\mathrm{HIMEDIA}^{\circledR}\right)$ and selective enrichment in $20 \mathrm{~mL}$ of tetrathionate broth with iodine (TT) (ACUMEDIA ${ }^{\circledR}$ ) and $20 \mathrm{~mL}$ of RappaportVassiliadis (RV) broth (ACUMEDIA ${ }^{\circledR}$ ) (BRASIL, 1995). Two grams of feces were added in BHI (HIMEDIA ${ }^{\circledR}$ ) and TT (ACUMEDIA ${ }^{\circledR}$ ) broths and $0.2 \mathrm{~g}$ in RV broth $\left(A C U M E D I A^{\circledR}\right)$. For the $B A X^{\circledR}$ System and MSRV methods, $2 \mathrm{~g}$ of feces were added to $20 \mathrm{~mL}$ of buffered peptone water (BPW) $\left(\right.$ MERCK $\left.^{\circledR}\right)$ added to a volume of $1 \mathrm{~mL}$ of the inoculum to be tested.

Each of the collected DSC were individually added to a beaker containing $80 \mathrm{~mL}$ of BPW (MERCK ${ }^{\circledR}$ ) and, after homogenization, a volume of $5.7 \mathrm{~mL}$ of the resulting liquid was transferred to a sterile test tube, containing $0.3 \mathrm{ml}$ of the inoculum to be tested.

\section{Traditional method of identifying SE and ST in feces and DSC samples}

For the analysis of feces and DSC samples by the traditional method, the procedures were carried out according to the recommendations of Portaria $n^{\circ} 126$ of MAPA (Brasil, 1995).

The samples were prepared as described above, firstly enriched in the selective broths TT (ACUMÉDIA $\left.{ }^{\circledR}\right)$ and RV (ACUMÉDIA $\left.{ }^{\circledR}\right)$ and then incubated at $42^{\circ} \mathrm{C}$, all for 24 hours.

To differentiate Salmonella after enrichment the following culture media were used: MacConkey agar $\left(\mathrm{OXOID}^{\circledR}\right)$, Hektoen agar $\left(\mathrm{HIMEDIA}^{\circledR}\right)$, and BPLS agar (modified bright green agar) (MICROMED ${ }^{\circledR}$ ), all incubated at $37^{\circ} \mathrm{C}$ for 24 hours. Typical colonies were seeded on Rambach agar (MERCK $\left.{ }^{\circledR}\right)$ and incubated at $37^{\circ} \mathrm{C}$ for 24 hours to confirm purity.

Biochemical tests started from the selection of two to three red colonies identified in Rambach (MERCK ${ }^{\circledR}$ ) and replicated in TSI Agar (triple iron sugar agar) (MICROMED ${ }^{\circledR}$ ), LIA (lysine agar and iron) (MICROMED ${ }^{\circledR}$ ), SIM (Sulphite, Indole, and Motility) (HIMEDIA ${ }^{\circledR}$ ) and Urea broth (MICROMED ${ }^{\circledR}$ ). After confirmation, complementary tests followed, including oxidase, catalase, indole, Voges-Proskauer, hydrogen sulfide, Simons citrate, lysine, and ornithine decarboxylase, lactose, sucrose, maltose, acid production, malonate, phenylalanine deaminase, methyl-red tests, arginine, mannitol, dulcitol and maltose (Brasil, 1995).

The strains compatible with Salmonella were characterized antigenically with polyvalent Salmonella anti-somatic serum (PROBAC $\left.{ }^{\circledR}\right)$, according to the manufacturer's recommendations (Brasil, 1995).

\section{MSRV method of identifying SE and ST in feces and DSC samples}

The detection of Salmonella using the MSRV was done according to the procedures described in ISO 6579:2002/DAM (ISO, 2005).

The feces and DSC samples were incubated in BPW $\left(\mathrm{MERCK}^{\circledR}\right)$ at $37^{\circ} \mathrm{C}$ for 24 hours. Then, the volume of $100 \mu \mathrm{L}$ was sown by the drip method on MSRV plates and incubated at $42^{\circ} \mathrm{C}$ for 24 to 48 hours. The halo formation indicated a positive result. Confirmation was carried out by raising two and three suspected colonies on Rambach agar $\left(\mathrm{MERCK}^{\circledR}\right)$, followed by the biochemical and antigenic characterization described above (Brasil, 1995).

\section{BAX ${ }^{\circledR}$ System method for SE and ST identification in feces and DSC samples}

The $B A X^{\circledR}$ automated PCR system was used to check the presence of Salmonella in DSC and feces, following different enrichment protocols for each type of sample, according to the manufacturer's instructions (User Guide 2010). The feces and DSC samples in BPW $\left(\mathrm{MERCK}^{\circledR}\right.$ ) were incubated at $37^{\circ} \mathrm{C}$ for 24 hours.

For the proposed matrix, $10 \mu \mathrm{L}$ of the pre-enriched sample in BPW $\left(\mathrm{MERCK}^{\circledR}\right)$ was transferred to $500 \mu \mathrm{L}$ of $\mathrm{BHI}\left(\mathrm{MERCK}^{\circledR}\right)$ and incubated at $37^{\circ} \mathrm{C}$ for 3 hours (regrowth) (User Guide, 2010). Then, $5 \mu \mathrm{L}$ of the sample was subjected to the lysis reaction in phosphate buffer (Figure 2b). For feces, selective enrichment in Tetrathionate Hajna broth was performed with iodine (TT Hajna) and RV broth (ACUMEDIA ${ }^{\circledR}$ ) after preenrichment in BPW. Then, $10 \mu \mathrm{L}$ of the sample was subjected to the lysis reaction in phosphate buffer. (Figure 2a).

For lysis, the mixture was heated to $37{ }^{\circ} \mathrm{C}$ for 20 minutes and $95{ }^{\circ} \mathrm{C}$ for 10 minutes for protein inactivation. The samples were submitted to real-time $P C R$ in tubes with reagents (primers, dNTPs, Taq-DNA polymerase, fluorescent dye, internal positive control, and other necessary reagents for PCR). 


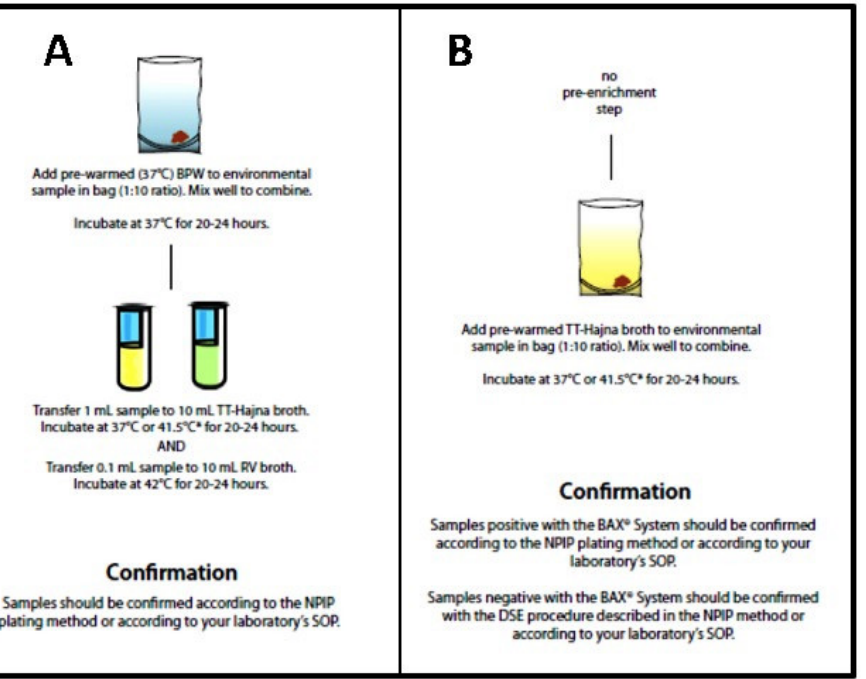

Figure 2 - The protocol recommended by National Poultry Improvement Plan (NPIP) for testing Salmonella in fecal (a) and environmental (b) samples for the BAX ${ }^{\circledR}$ System method (USER GUIDE, 2010).

\section{Statistical analysis}

To analyze the results, relative accuracy, sensitivity, specificity and positive and negative predictive values were calculated using SAS (Statistical Analysis Systems), and to assess the accuracy of the analyzed methods, repeatability (measure of conformity) and reproducibility were calculated. The comparison between the repetitions of the inoculum used in the study was performed using the Fisher exact test and for the calculation of the indices the z-test was used (Graph Pad Prism 8.0).

\section{RESULTS}

The biochemical characterization of Salmonella strains used in the study confirmed the genus and ribotyping allowed the determination of serovars SE and ST, with similarity equal to or greater than $89 \%$ within each serovar. All strains of SE belong to the ribogroup (Pvull 222-203-S-1). ST strains were identified in the Pvull 222-203-S-3 and Pvull 222-203S-7 ribogroups.

The test with the experimental inoculum used average amounts of 12 and 126 CFU of SE and ST. The smallest inoculum showed a low recovery capacity of the bacterium when in the presence of feces, due to the fact that in only one of the repetitions we obtained a recovery greater than $50 \%$, indicating that the traditional reference method did not provide consistent results with this number of cells, as shown in table 1. Therefore, for the validation of the other methodologies com a presença de matriz, we use an inocula 2 CFU log averages, therefore considered our detection limit.
Table 1 - Recovery of SE and ST cells by the traditional method after inoculation in series of ten tubes.

\begin{tabular}{lcc}
\hline Average inoculum (CFU) & Repetition* & $\begin{array}{c}\text { Recovery } \\
\mathrm{N}(\%)\end{array}$ \\
\hline \multirow{3}{*}{$12 \pm 6.42^{\mathrm{a}}$} & $\mathrm{R} 1$ & $2(20)$ \\
& R2 & $3(30)$ \\
& R3 & $6(60)$ \\
$126 \pm 35.84^{\mathrm{b}}$ & R4 & $3(30)$ \\
& R1 & $9(90)$ \\
& R2 & $1(10)$ \\
\hline \multirow{2}{*}{10} & R3 & $5(50)$ \\
\hline
\end{tabular}

*10 replicates per repetition. $\mathrm{N}=$ number of positive replicates regarding the number of inoculated. Different letters in the column indicates a significant difference (Fischer test).

The individual results obtained in the three methods of analysis to determine the presence of SE and ST in samples of DSC and feces can be seen in Table 2. The general average of inoculated cells in all repetitions was 126 CFU, being 127 for ST and 130 CFU for SE.

We did not observe any significant difference between the tests, either according to the type of contaminated sample, or considering the serovar used, which demonstrated the equivalence of the techniques. The existence of positive samples in the control group may be related to the presence of the agent in undetectable quantities in the primary analysis of the sample, but that during the experimental phase there was sufficient multiplication for the detection of the microorganism.

Less agreement (repeatability) and reproducibility was observed in the BAX ${ }^{\circledR}$ System method for analysis of DSC contaminated with SE. For the remaining cases, we observed satisfactory percentages, above $80 \%$ of repeatability and reproducibility in the tested methodologies (Table 3).

The sensitivity of the methods for both serovars and matrices analyzed was greater than $80 \%$ and in $10 / 12$ results greater than or equal to $90 \%$. On both occasions when indices of less than $90 \%$ of sensitivity were obtained, the serovar involved was SE (Table 4).

All tests showed good specificity (95\% to $100 \%)$ and accuracy (90\% to $100 \%$ ), and the calculation of this last index considered all the obtained results in the test and control samples (Table 4).

The analysis of feces samples showed that the relative accuracy of the $B A X^{\circledR}$ System varied between $86 \%$ and $100 \%$ and MSRV between $90 \%$ and $100 \%$. The relative sensitivity of the $B A{ }^{\circledR}$ System varied between 90\% and 100\% and MSRV between 95\% and $100 \%$. This demonstrated that the alternative methods, for researching SE and ST in feces, were 
Table 2 - Frequency and percentage of positivity in samples of feces and DSC inoculated with Salmonella (test) and control, in the different replications using the BAX ${ }^{\circledR}$, traditional, and MSRV analysis methods.

\begin{tabular}{|c|c|c|c|c|c|c|c|c|}
\hline \multirow{2}{*}{$\begin{array}{l}\text { Sample/ } \\
\text { Serovar }\end{array}$} & \multirow{2}{*}{ Repetition* } & \multirow{2}{*}{$\begin{array}{l}\text { Average inoculum (log } \\
\text { CFU) }\end{array}$} & \multicolumn{3}{|c|}{ Test - n(\%) } & \multicolumn{3}{|c|}{ Control - n(\%) } \\
\hline & & & Bax & TRM & MSRV & Bax & TRM & MSRV \\
\hline \multirow{3}{*}{ DSC/SE } & R1 & $2.29 \pm 0.23^{\mathrm{a}}$ & 4 & 6 & 7 & 0 & 1 & 0 \\
\hline & R2 & $2.14 \pm 0.22^{\mathrm{a}}$ & 6 & 7 & 7 & 0 & 0 & 0 \\
\hline & R3 & $2.05 \pm 0.07^{\mathrm{a}}$ & 6 & 7 & 7 & 0 & 0 & 0 \\
\hline Total & & & $16(76.2)^{\mathrm{a}}$ & $20(95.2)^{a}$ & $21(100)^{a}$ & $0^{\mathrm{a}}$ & $1(4.8)^{\mathrm{a}}$ & $0^{\mathrm{a}}$ \\
\hline \multirow{3}{*}{ DSC/ST } & R1 & $2.12 \pm 0.08^{a}$ & 7 & 6 & 7 & 0 & 0 & 0 \\
\hline & R2 & $2.18 \pm 0.07^{a}$ & 5 & 7 & 7 & 0 & 1 & 0 \\
\hline & R3 & $2.17 \pm 0.03^{\mathrm{a}}$ & 7 & 7 & 7 & 1 & 0 & 0 \\
\hline Total & & & $19(90.4)^{\mathrm{a}}$ & $20(95.2)^{a}$ & $21(100)^{a}$ & $1(4.8)^{\mathrm{a}}$ & $1(4.8)^{\mathrm{a}}$ & $0^{a}$ \\
\hline \multirow{3}{*}{ Feces/SE } & R1 & $2.05 \pm 0.06^{a}$ & 6 & 7 & 7 & 0 & 0 & 0 \\
\hline & R2 & $2.01 \pm 0.09^{a}$ & 7 & 5 & 6 & 0 & 0 & 0 \\
\hline & R3 & $2.06 \pm 0.06^{a}$ & 6 & 6 & 7 & 0 & 0 & 0 \\
\hline Total & & & $19(90.4)^{a}$ & $18(85.7)^{\mathrm{a}}$ & $20(95.2)^{a}$ & $0^{a}$ & $0^{a}$ & $0^{a}$ \\
\hline \multirow{3}{*}{ Feces/ST } & R1 & $2.09 \pm 0.06^{a}$ & 7 & 7 & 7 & 0 & 0 & 0 \\
\hline & R2 & $2.08 \pm 0.07^{a}$ & 5 & 5 & 6 & 0 & 0 & 0 \\
\hline & R3 & $2.18 \pm 0.07^{a}$ & 7 & 7 & 7 & 0 & 0 & 0 \\
\hline Total & & & $19(90.4)^{\mathrm{a}}$ & $19(90.4)^{a}$ & $20(95.2)^{a}$ & $0^{a}$ & $0^{a}$ & $0^{a}$ \\
\hline
\end{tabular}

* Seven replicates per repetition; BAX=BAX ${ }^{\circledR}$ system; TRM=traditional reference method (BRASIL, 1995); MSRV=Modified Rappaport-Vassiliadis Semi-solid Medium (ISO 6579: 2002 I DAM). Equal letters in the rows and columns indicate equivalent results evaluated separately in the control and test (Fischer test - $p>0.05$ ).

Table 3 - Repeatability and reproducibility in matrices of feces and DSC inoculated and not inoculated with SE and ST, analyzed by the traditional, BAX ${ }^{\circledR}$ System and MSRV methods.

\begin{tabular}{|c|c|c|c|c|c|}
\hline \multirow{2}{*}{ Sample-Serovar } & \multirow{2}{*}{ Methods } & \multicolumn{2}{|c|}{ Amostras fortificadas } & \multicolumn{2}{|c|}{ Negative control } \\
\hline & & Repe (\%) & Repro (\%) & Repe (\%) & Repro (\%) \\
\hline \multirow{3}{*}{ DSC-ST } & TRM & 95 & 90 & 95 & 90 \\
\hline & BAX & 90 & 81 & 95 & 90 \\
\hline & MSRV & 100 & 100 & 100 & 100 \\
\hline \multirow{3}{*}{ DSC-SE } & TRM & 95 & 90 & 95 & 90 \\
\hline & BAX & 76 & 52 & 100 & 100 \\
\hline & MSRV & 95 & 90 & 100 & 100 \\
\hline \multirow{3}{*}{ Feces-ST } & TRM & 95 & 90 & 100 & 100 \\
\hline & BAX & 90 & 81 & 100 & 100 \\
\hline & MSRV & 95 & 90 & 100 & 100 \\
\hline \multirow{3}{*}{ Feces-SE } & TRM & 86 & 71 & 100 & 100 \\
\hline & BAX & 90 & 81 & 100 & 100 \\
\hline & MSRV & 90 & 81 & 100 & 100 \\
\hline
\end{tabular}

TRM=Traditional reference method (BRASIL, 1995); BAX=BAX ${ }^{\circledR}$ system; MSRV=Modified Rappaport-Vassiliadis semi-solid medium (ISO 6579: 2002/DAM); Repe=Repeatability; Repro=Reproducibility.

corresponding with the traditional reference method (Table 5).

For the samples of DSC, we observed that for the $B A{ }^{\circledR}$ System the relative accuracy was between $73 \%$ and $95 \%$. The MSRV showed $95 \%$ of relative accuracy with the traditional method, for contaminated samples. The relative sensitivity of the BAX ${ }^{\circledR}$ System was $90 \%$ for ST and $71 \%$ for SE, and for MSRV it was 100\% for both serovars. The analysis of the control samples showed $100 \%$ of relative specificity, except for the BAX ${ }^{\circledR}$ System contaminated with ST, which was $95 \%$ (Table 5).

The individual analysis of the obtained results in the reference method for the test and control samples compared to the results obtained for the same samples in the alternative methods (MT x BAX; MT x MSRV) allowed to verify that they have similar performances, with the establishment of conformity for both tested serovars and matrices (Table 6).

\section{DISCUSSION}

Considering all the necessary steps for the performance of traditional methods like the official Brazilian method for the detection of Salmonella spp. it takes a lot of time and work until the final diagnosis is reached, which ends up slowing down the production process and the release of the product 
Table 4 - Sensitivity, specificity, and accuracy and PPV and NPV of the traditional, BAX ${ }^{\circledR}$ System and MSRV methods for the diagnosis of SE and ST in samples of DSC and feces.

\begin{tabular}{|c|c|c|c|c|c|c|c|}
\hline \multirow[t]{4}{*}{ Matrices } & Serovar & Methods & $\begin{array}{l}\text { Sensitivity } \\
\mathrm{Cl}(95 \%)\end{array}$ & $\begin{array}{l}\text { Specificity } \\
\mathrm{Cl}(95 \%)\end{array}$ & $\begin{array}{l}\text { Accuracy } \\
\mathrm{Cl}(95 \%)\end{array}$ & $\begin{array}{c}\text { PPV } \\
\mathrm{Cl}(95 \%)\end{array}$ & $\begin{array}{c}\text { NPV } \\
\mathrm{Cl}(95 \%)\end{array}$ \\
\hline & & & $P$ & $\mathrm{P}$ & $p$ & $\mathrm{P}$ & $\mathrm{P}$ \\
\hline & & TRM & 0.95 & 0.95 & 0.95 & 0.95 & 0.95 \\
\hline & ST & BAX & 0.90 & 0.95 & 0,93 & 1.00 & 0.91 \\
\hline \multirow[t]{6}{*}{ DSC } & & MSRV & 1.00 & 1.00 & 1.00 & 1.00 & 1.00 \\
\hline & & TRM & 0.95 & 0.95 & 0.95 & 0.95 & 0.95 \\
\hline & SE & BAX & 0.81 & 1.00 & 0.90 & 1.00 & 0.81 \\
\hline & & MSRV & 1.00 & 1.00 & 1.00 & 1.00 & 1.00 \\
\hline & & TRM & 0.95 & 1.00 & 0.98 & 1.00 & 0.91 \\
\hline & ST & BAX & 0.90 & 1.00 & 0.95 & 1.00 & 0.91 \\
\hline \multirow[t]{4}{*}{ Feces } & & MSRV & 0.95 & 1.00 & 0.98 & 1.00 & 0.95 \\
\hline & & TRM & 0.86 & 1.00 & 0.93 & 1.00 & 0.88 \\
\hline & SE & BAX & 0.90 & 1.00 & 0.95 & 1.00 & 0.91 \\
\hline & & MSRV & 1.00 & 1.00 & 1.00 & 1.00 & 0.95 \\
\hline
\end{tabular}

TRM=Traditional reference method (BRASIL, 1995); BAX=BAX® system; MSRV=Modified Rappaport-Vassiliadis semi-solid medium (ISO 6579: 2002/DAM); PPV= positive predictive value; $N P V=$ negative predictive value; $C l(95 \%)=$ confidence interval of $95 \%$; $p=$ relative percentage.

Table 5 - Relative accuracy, sensitivity, and specificity of the BAX ${ }^{\circledR}$ System and MSRV alternative methods regarding to the traditional reference method, compared by analysis of feces and DSC contaminated with SE and ST.

\begin{tabular}{|c|c|c|c|c|c|c|}
\hline \multirow[b]{2}{*}{ Matrices } & \multirow[b]{2}{*}{ Serovar } & \multirow[b]{2}{*}{ Method } & \multicolumn{2}{|c|}{ Positive control } & \multicolumn{2}{|c|}{ Negative control } \\
\hline & & & $\begin{array}{l}\text { Relative Accuracy } \\
\qquad \mathrm{Cl}(95 \%)\end{array}$ & $\begin{array}{l}\text { Relative Sensitivity } \\
\qquad \mathrm{Cl}(95 \%)\end{array}$ & $\begin{array}{l}\text { Relative Accuracy } \\
\qquad \mathrm{Cl}(95 \%)\end{array}$ & $\begin{array}{l}\text { Relative Specificity } \\
\text { CI (95\%) }\end{array}$ \\
\hline \multirow{4}{*}{ Feces } & \multirow{2}{*}{ ST } & BAX & 0.86 & 0.90 & 1.00 & 1.00 \\
\hline & & MSRV & 0.90 & 0.95 & 1.00 & 1.00 \\
\hline & \multirow{2}{*}{ SE } & BAX & 0.86 & 0.90 & 1.00 & 1.00 \\
\hline & & MSRV & 0.95 & 1.00 & 1.00 & 1.00 \\
\hline \multirow{4}{*}{ DSC } & \multirow{2}{*}{ ST } & BAX & 0.86 & 0.90 & 0.90 & 0.95 \\
\hline & & MSRV & 0.95 & 1.00 & 0.95 & 1.00 \\
\hline & \multirow{2}{*}{ SE } & BAX & 0.73 & 0.71 & 0.95 & 1.00 \\
\hline & & MSRV & 0.95 & 1.00 & 0.95 & 1.00 \\
\hline
\end{tabular}

$B A X=B A{ }^{\circledR}$ system; MSRV=Modified Rappaport-Vassiliadis semi-solid medium (ISO 6578: 2002/DAM); CI (95\%) = confidence interval of 95\%.

to the market, generating expenses for industries and consumers. In addition, the longer the time taken to reach the diagnosis, the more time it will take to carry out corrective and preventive actions in cases of non-compliance with the expected microbiological quality, which may aggravate situations that could be resolved more quickly if the diagnosis were faster
(Franchin, 2008). Alternative methods, such as MSRV (ISO 6579) and PCR (BAX ${ }^{\circledR}$ System) are viable options when considering detection performance and costbenefit, however, it is important to highlight some considerations. The MSRV agar (ISO 6579) reduces the possibilities of false-positive diagnoses and speeds up the analytical process (Rodríguez, Busca e Bueno,

Table 6 - Conformity test for alternative methods (BAX ${ }^{\circledR}$ System and MSRV) regarding to the traditional reference method, for matrices of feces and DSC contaminated with ST and SE.

\begin{tabular}{|c|c|c|c|c|c|c|c|c|}
\hline \multirow{2}{*}{ Matrices } & \multirow{2}{*}{ Methods } & \multirow{2}{*}{ Serovar } & \multicolumn{3}{|c|}{ Positive control } & \multicolumn{3}{|c|}{ Negative control } \\
\hline & & & $\mathrm{Xo}_{\mathrm{O}}=$ & For $n=21$ & Decision & $\mathrm{XO}_{\mathrm{O}}=$ & For $n=21$ & Decision \\
\hline \multirow{4}{*}{ Feces } & \multirow{2}{*}{ BAX } & ST & 3 & $<7$ & Conformity & 0 & $<7$ & Conformity \\
\hline & & SE & 3 & $<7$ & Conformity & 0 & $<7$ & Conformity \\
\hline & \multirow{2}{*}{ MSRV } & ST & 2 & $<7$ & Conformity & 0 & $<7$ & Conformity \\
\hline & & SE & 4 & $<7$ & Conformity & 0 & $<7$ & Conformity \\
\hline \multirow{4}{*}{ DSC } & \multirow{2}{*}{ BAX } & ST & 3 & $<7$ & Conformity & 2 & $<7$ & Conformity \\
\hline & & SE & 4 & $<7$ & Conformity & 1 & $<7$ & Conformity \\
\hline & \multirow{2}{*}{ MSRV } & ST & 2 & $<7$ & Conformity & 0 & $<7$ & Conformity \\
\hline & & SE & 1 & $<7$ & Conformity & 0 & $<7$ & Conformity \\
\hline
\end{tabular}

BAX=BAX® system; MSRV=Modified Rappaport-Vassiliadis semi-solid medium (ISO 6579: 2002/DAM); Xo=number of non-compliant results; $n=$ sample size; ${ }^{*}=$ based on the critical value of $z<-1.6448$. 
2018), being advantageous for the food industry, both for more accurate detection in the prevalence of the pathogen, as well as in the reduction of costs with time and space to the storage of flocks that are under analysis. However, this method is not able to detect immobile strains (not evaluated in this study) but it is important in poultry production and health. On the other hand, the diagnosis based on bacterial DNA, such as the Bax System can suffer from the interference of compounds present in some matrices. In this study, we observed interferences in the analysis of the environment with the use of disposable shoe covers, probably related to the presence of DNAses or other interfering substances in the amplification reaction. In general, the cost of traditional or alternative methods is highly variable, as they are directly linked to the number of tests performed and the value of the labor involved. Alternative methods have advantages mainly for the productive sector, as they generally reduce labor and allow results to be obtained in a shorter time, which allows the rapid implementation of corrective actions to mitigate the dangers that positive results for SE or ST may represent for the economy and public health.

The confirmation of the strains used in the study as belonging to the proposed serovars was done using a ribotyping technique combined with the previous biochemical phenotypic screening. In ribotyping, probes derived from highly conserved sequences of the genes encoding ribosomal RNA (rRNA) are used to typify bacteria (Aarestrup, 2006; Rodriguez-Lázaro et al., 2007). In this technique, it is also possible to digest the amplified fragments with a restriction enzyme, perform the electrophoretic run, transfer the denatured fragments to a filter, hybridize with a marked probe and reveal the band patterns (Gandra et al., 2008). Automated ribotyping using Riboprinter ${ }^{\circledR}$ can identify genus, species, and serovar, when the similarity of the restriction profile obtained, is equal to or greater than $87 \%$ with the profiles existing in the device library.

The definition of the experimental inoculum close to $2 \log$ CFU, referring to the average number of 126 CFU of Salmonella, is consistent with a study by Froder (2008) that established that the limit of detection of ST in swine feces was 100 CFU/g and another research performed by Santos et al. (2001) developed a PCR protocol to detect SE and ST in chicken meat samples whose average detectable inoculum was 120 CFU and 200 CFU, respectively.

The need for a greater number of Salmonella cells to obtain positive results may be related to the large number of competing contaminants in the matrices used and/or the difficulty in the inoculum distribution, which is evident when comparing the results obtained in the different replicates (Table 1).

The statistical similarity in the three used tests shows that the two proposed methodologies can be used in an equivalent way to the traditional method for analyzing SE and ST in environmental samples of poultry origin.

According to American Standard For Testing Materials (ASTM) (2016), the repeatability of a method is the ability to repeat a result in the same samples, in the same place, with the same equipment and the same operator; and reproducibility is the ability to reproduce a result in the same samples, in different locations, with different equipment and different operators.

The lower concordance and reproducibility presented by the BAX ${ }^{\circledR}$ System method in samples of DSC with SE may be a consequence of the non-homogeneous distribution of the inoculum in the matrix allied to the lower sample rate used for the analysis in this method, equivalent to $5 \mu \mathrm{L}$ that is considerably lower than those recommended for the other methods.

The sensitivity of a diagnostic method is the proportion of true positives detected by this method, that is, the proportion of samples that contain the target microorganism and that provide a positive result in the method in question. Thus, sensitive tests will have a low number of false-negative results (OIE, 2011). For the two occasions when the sensitivity was less than $90 \%$ in which the serovar involved was SE, likely, this serovar is more influenced by competition with the contaminating microbiota present in the matrix, than ST.

All tests showed high specificity and accuracy, greater than or equal to $90 \%$. Specificity shows the high proportion of true negative results detected by all methodologies. A specific test offers little risk of providing false-positive results (Albano, 2009). In our study, specificity dealt with the proportion of samples that do not have Salmonella and that have a negative diagnostic test result. The accuracy proved the quality of the results offered by all methods.

The relative analyzes of relative sensitivity, specificity, and accuracy showed agreement between the methodologies for the two types of analyzed matrices. However, slightly lower rates were found in feces samples, probably due to the nature of the matrix, the high rate of contaminants, the presence of mucus, homogeneity of the inoculum, and other factors. Therefore, due to its practicality and quickness 
Coelho LR, Melo RT, Monteiro GP, Reischak D, Mendonça AO, Tavares AAS, Rossi DA

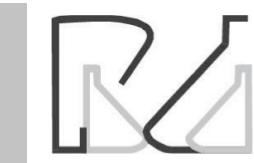

in collecting the samples, the DSC proved to be the most qualified way to use the tested methodologies. The analyzes must be carried out as close as possible to the date of the slaughter of the poultry flock, in such a way that the results are known before being sent to the slaughterhouse (IN 20, 2016).

The alternative methodologies, in addition to good cost-benefit performance, presented results equivalent to the traditional Salmonella analysis method. There was satisfactory performance regarding sensitivity, specificity, repeatability and reproducibility, allowing us to affirm that, for feces and DSC, the alternative methods $B A X^{\circledR}$ System and Modified Semi-solid Rappaport-Vassiliadis (MSRV) (ISO 6579) are equivalent to the official Brazilian method (Portaria 126 - MAPA).

\section{ACKNOWLEDGMENTS}

Thanks to LANAGRO team for providing the necessary material for research and helps in carrying out the analyzes.

\section{REFERENCES}

Aarestrup M. Antimicrobial resistance in bacteria of animal origin. Washington: ASM Press; 2006.

ABPA - Associação Brasileira de Proteína Animal. Relatório anual; 2020 [cited 2020 May 29]. Available from: http://abpa-br.org/wp-content/ uploads/2020/05/abpa_relatorio_anual_2020_portugues_web.pdf

Albano FM, Raya-Rodriguez MT. Validação e garantia de ensaios laboratoriais. Porto Alegre: Rede Metrológica; 2009

ASTM - American Standard for Testing Materials. ASTM E691: Standard practice for conducting an interlaboratory study to determine the precision of a test method. West Conshohocken; 2016. 22p.

Brasil. Ministério da Agricultura, Pecuária e Abastecimento. Portaria n. 126, de 03 de novembro de 1995. Aprova as normas de credenciamento e monitoramento de laboratórios de diagnóstico das salmoneloses aviárias (S. Enteritidis, S. Gallinarum, S. Pullorum e S. Typhimurium). Diário Oficial da União, Brasília, DF; 1995.

Commission Regulation (EC) No 200/2012 of 8 March 2012 concerning a Union target for the reduction of Salmonella Enteritidis and Salmonella Typhimurium in flocks of broilers, as provided for in Regulation (EC) No 2160/2003 of the European Parliament and of the Council. OJ L 71, 9.3.2012, p. 31-36.
Validation of Alternative Methods of Detection of Salmonella Spp. in Experimentally Contaminated Poultry Environmental Samples

Franchin, P. R. (2008). Comparação de metodologias alternativas para detecção de Salmonella sp. e Listeria monocytogenes em carnes e produtos cárneos. Tese de Doutorado. 114f. Universidade Federal de Santa Catarina, Centro de Ciências Agrárias, Departamento de Ciências e Tecnologia de Alimentos, Programa de Doutorado em Ciências dos Alimentos

Froder $\mathrm{H}$. Desenvolvimento de métodos para a quantificação direta de Salmonella sp. por PCR-tempo real e por transcriptase reversa - PCRtempo real [tese]. São Paulo (SP): Faculdade de Ciências Farmacêuticas, Universidade de São Paulo; 2008.

Gandra EA, Gandra TKV, Mello WS, Godoi HS. Técnicas moleculares aplicadas à microbiologia de alimentos. Acta Scientiarum Technology 2008;(30):109-118.

ISO - International Organization for Standardization. Microbiology of food and animal feeding stuffs - Horizontal method for the detection of Salmonella spp [ ISO 6579]. Geneva; 2002.

OIE - World Organization For Animal Health. Terrestrial animal health code. Prevention, detection and control of Salmonella in poultry. 2011 [cited 2020 May 28]. Available from: http://web.oie.int/eng/normes/mcode/ en_chapitre_1.6.5.pdf

Rodríguez, F. I., Procura, F., Bueno, D. J. Comparison of 7 culture methods for Salmonella serovar Enteritidis and Salmonella serovar Typhimurium isolation in poultry feces. Poultry Science; 2018. 97: 3826-3836.

Rodriguez-Lazaro D, Lombard B, Smith H, Rzezutka A, D'agostino M. Trends in analytical methodology in food safety and quality: monitoring microorganisms and genetically modified organisms. Trends in Food Science Technology 2007;(18):306-319.

Santos LR, Nascimento VP, Oliveira SD, Flores ML, Pontes AP, Ribeiro AR, et al. Polymerase Chain Reaction (PCR) for the detection of Salmonella in artificially inoculated chicken meat. Revista do Instituto de Medicina Tropical de São Paulo 2001;(43):247-250.

Soria MC, Soria MA, Procura F, Rodriguez I, Godano El. Egg production systems and Salmonella in South America. In: Ricke SC, Gast RK. Producing safe eggs: microbial ecology of Salmonella. London: Academic Press; 2017. p.87-110.

Secretaria de Vigilância em Saúde. Surtos de doenças transmitidas por alimentos no Brasil [informe 2018]. Brasília (DF): Ministério da Saúde, Brasil; 2019 [cited 2020 May 31]. Avaliable from: http://portalarquivos2. saude.gov.br/images/pdf/2019/fevereiro/15/Apresenta----o-SurtosDTA---Fevereiro-2019.pdf

User'S Guide. Bax ${ }^{\circledR}$ System PCR assay with automated detection for bacterial screening. Wilmington: Du Pont Qualicon; 2010.

Young, I., Wilhelm, B. J., Cahill, S., Nakagawa, R., Desmarchelier, P., Rajić, A. A Rapid Systematic Review and Meta-Analysis of the Efficacy of Slaughter and Processing Interventions to Control Non-Typhoidal Salmonella in Beef and Pork. Journal of Food Protection; 2016. 79: 2196-2210. 